\title{
Biochemical changes following electro-acupuncture and static magnetic field therapy in rabbits for bone defect healing
}

\author{
Girraj Shakya, M. M. S. Zama, H. P. Aithal, Reihii J ohn and Mahendra Baghel \\ Division of Surgery \\ Indian Veterinary Research Institute, Izatnagar - 243122, Dist. Bareilly, Uttar Pradesh, India \\ Corresponding author: M. M. S. Zama, email: mmszama@yahoo.com \\ Received: 17-11-2013, Revised: 11-01-2014, Accepted: 23-01-2014, Published online: 18-02-2014
}

doi: 10.14202/vetworld.2014.83-86

How to cite this article: Shakya G, Zama MMS, Aithal HP, John R and Baghel M (2014) Biochemical changes following electro-acupuncture and static magnetic field therapy in rabbits for bone defect healing, Veterinary World 7(2): 83-86.

\begin{abstract}
Aim: To evaluate the effect of Electro-Acupuncture (EA) and Static Magnetic Field (SMF) therapy on healing of bone defect in rabbits.

Materials and Methods: A $2 \mathrm{~mm}$ bone defect was created at radial midshaft of $18 \mathrm{New}$ Zealand White rabbits. The animals were then randomly divided into 3 equal groups. The animals in the group A did not receive any physiotherapy and served as control. Group B animals were treated with the EA using $50 \mathrm{~Hz}$ and 3-10 mA DD current for $10 \mathrm{~min}$. Group C animals were treated with SMF therapy on alternate days till day 15 . Activity of serum calcium (Ca), potassium (P) and ALP; Plasma Cortisol and LPO were evaluated preoperatively and on days 7, 15,30 and 60 of experiment.
\end{abstract}

Results: Postoperatively, SMF therapy treated animals exhibited higher Ca, P and ALP level and low initial level of Cortisol and LPO as compared to EA and control group animal.

Conclusion: SMF and EA had positive effect on bone defect healing and early resolution of stress, induced due to creation of bone defect, however SMF had an edge over EA.

Keywords: bone defect healing, electro acupuncture, static magnetic field.

Abbreviations: ALP- alkaline phosphatase, SMF- static magnetic field, EA- electro acupuncture, PMF- pulsed magnetic field, LPO- lipid peroxidation.

\section{I ntroduction}

A variety of biological, mechanical and physical interventions have been developed to enhance healing of fractures. Pulsed magnetic field therapy (PMF) has been used to treat various conditions such as inflammation, osteoarthritis, soft-tissue injuries, chronic pelvic pain and tendonitis. PMF therapy has also been reported to be useful for nerve regeneration, healing of osseous defects, bone grafts and fractures, prevention of osteoporosis [1] and increased mineralization [2]. Animal experiments have shown that long-term local static magnetic field (SMF) stimulation also increases bone strength [3] and bone healing process [4]. SMF has also been shown to have a stimulatory effect on regional blood flow to the extremities [1], enhances osteoblastic maturation by up-regulating local factors [5], reduces inflammation by constricting capillaries [6] and also reduces the pain perception due to removal of the toxic byproduct of inflammation such as bradykinins and prostaglandin [7]. Electro acupuncture (EA) therapy has also been used in recent years for the control of pain by enhancing the secretion of endorphin in the plasma and central nervous system [8]. In addition to reducing pain and increasing ambulation [9], acupuncture appears to

Copyright: The authors. This article is an open access article licensed under the terms of the Creative Commons Attribution License (http://creativecommons.org/licenses/by/2.0) which permits unrestricted use, distribution and reproduction in any medium, provided the work is properly cited. increase circulation and lymphatic drainage around the affected area and thus plays an important role in postoperative fracture management $[10,11]$.

The aim of the current study was to investigate the beneficial effects of SMF and EA in healing bone defects.

\section{Materials and Methods}

In the present study, 18 New Zealand White adult rabbits of both sexes, 6-8 months old, clinically healthy, average weight $1-1.3 \mathrm{~kg}$ were used. Eight hours prior to surgical procedures, animals were only provided with access to water but feed was withheld. All the animals were maintained under similar housing and feeding conditions.

Ethical approval: Use of the animals in experimental procedures were approved by the Institutional Animal Ethics Committee.

Surgical procedure: Animals were first injected with xylazine $(6 \mathrm{mg} / \mathrm{kg}$ body weight), 10 minutes later ketamine $(60 \mathrm{mg} / \mathrm{kg}$ body weight) was given intramuscularly for induction of anesthesia [12]. Approximately $2 \mathrm{~mm}$ bone defect was created at mid shaft of right radius. Adequate stability was achieved by leaving the ulna intact without any fixation of the radius. The muscle and subcutaneous tissue were closed over using 4/0 absorbable catgut sutures and skin was sutured using 3-0 nylon with horizontal 
Table-1. Mean \pm SE values of calcium $(\mathrm{mg} / \mathrm{dl})$ in different groups at different intervals.

\begin{tabular}{llllll}
\hline Group & $\mathbf{0}$ day & $\mathbf{7}$ day & $\mathbf{1 5}$ day & $\mathbf{3 0}$ day & $\mathbf{6 0}$ day \\
\hline A & $11.24 \pm 0.65$ & $10.77 \pm 0.93$ & $10.94 \pm 0.41$ & $11.87 \pm 0.34$ & $12.96 \pm 0.81$ \\
B & $12.13^{\mathrm{b}} \pm 0.64$ & $10.13^{\mathrm{a}} \pm 0.43$ & $10.13^{\mathrm{a}} \pm 0.51$ & $14.1^{\mathrm{c}} \pm 0.47$ & $14.47^{\mathrm{c}} \pm 0.36$ \\
C & $12.45^{\mathrm{ab}} \pm 0.42$ & $10.32^{\mathrm{a}} \pm 0.85$ & $11.3^{\mathrm{a}} \pm 0.77$ & $14.38^{\mathrm{b}} \pm 0.37$ & $13.86^{\mathrm{b}} \pm 1.04$ \\
\hline
\end{tabular}

Values in the same row without a common superscript lettesr a- e are significantly different $(P<0.05)$. Values in the same column without a common superscript letter $A-E$ are significantly different $(P<0.05)$.

Table-2. Mean \pm SE values of phosphorus $(\mathrm{mg} / \mathrm{dl})$ in different groups at different intervals.

\begin{tabular}{llllll}
\hline Group & $\mathbf{0}$ day & $\mathbf{7}$ day & $\mathbf{1 5}$ day & $\mathbf{3 0}$ day & $\mathbf{6 0}$ day \\
\hline $\mathrm{A}$ & $5.35^{\mathrm{aA}} \pm 0.35$ & $5.6^{\mathrm{aA}} \pm 0.33$ & $6.29^{\mathrm{abA}} \pm 0.32$ & $6.80^{\mathrm{bA}} \pm 0.13$ & $6.83^{\mathrm{bA}} \pm 0.14$ \\
$\mathrm{~B}$ & $6.37^{\mathrm{aB}} \pm 0.22$ & $6.96^{\mathrm{abB}} \pm 0.51$ & $7.55^{\mathrm{abB}} \pm 0.36$ & $7.74^{\mathrm{bAB}} \pm 0.29$ & $7.76^{\mathrm{bAB}} \pm 0.59$ \\
$\mathrm{C}$ & $5.92^{\mathrm{aAB}} \pm 0.35$ & $7.41^{\mathrm{bB}} \pm 0.29$ & $9.02^{\mathrm{cC}} \pm 0.40$ & $8.26^{\mathrm{bCB}} \pm 0.56$ & $8.22^{\mathrm{bCB}} \pm 0.47$ \\
\hline
\end{tabular}

Values in the same row without a common superscript letter a- e are significantly different $(P<0.05)$. Values in the same column without a common superscript letter $A-E$ are significantly different $(P<0.05)$.

Table-3. Mean \pm SE values of alkaline phosphatase $(U / L)$ in different groups at different intervals.

\begin{tabular}{llllll}
\hline Group & $\mathbf{0}$ day & $\mathbf{7}$ day & $\mathbf{1 5}$ day & $\mathbf{3 0}$ day & $\mathbf{6 0}$ day \\
\hline $\mathrm{A}$ & $112.74^{\mathrm{b}} \pm 14.38$ & $125.55^{\mathrm{bA}} \pm 10.55$ & $127.24^{\mathrm{bA}} \pm 18.43$ & $145.81^{\mathrm{bA}} \pm 14.86$ & $64.99^{\mathrm{aA}} \pm 12.15$ \\
$\mathrm{~B}$ & $103.82^{\mathrm{a}} \pm 9.00$ & $135.05^{\mathrm{abA}} \pm 7.94$ & $194.76^{\mathrm{CBC}} \pm 19.65$ & $165.86 b^{\mathrm{CAB}} \pm 11.30$ & $137.27^{\mathrm{abAB}}+ \pm 13.47$ \\
$\mathrm{C}$ & $123.65^{\mathrm{a}} \pm 5.96$ & $206.79^{\mathrm{bCB}} \pm 16.47$ & $282.97^{\mathrm{dD}} \pm 16.34$ & $244.56^{\mathrm{cdC}} \pm 13.13$ & $180.63^{\mathrm{bB}} \pm 7.39$ \\
\hline
\end{tabular}

Values in the same row without a common superscript letter a- e are significantly different $(P<0.05)$ Values in the same column without a common superscript letter A- E are significantly different $(P<0.05)$.

mattress suture pattern. Postoperatively, all the animals were given intramuscular administration of cefotaxim $(50 \mathrm{mg} / \mathrm{kg})$ and meloxicam $(0.5 \mathrm{mg} / \mathrm{kg})$ body weight, once a day for 3 days. The animals were randomly divided in three equal groups.

The animals in the group A did not receive any physiotherapy and served as control group. Group B animals were treated with the EA given at acupoints LI4, LI-11, GB-39 and ST-36 using $50 \mathrm{~Hz}$ and 3-10 mA DD current for $10 \mathrm{~min}$ on alternate days till day 15 . Animals of group $\mathrm{C}$ were subjected to SMF therapy with two bipolar permanent magnet bars (each of 7001000 gauss strength), incorporated in splint bandage applied on the area with the north and south poles in opposite direction of each other. Therapy was given continuously till day 15 , except while administering the radiographic procedure (i.e. 20 - $30 \mathrm{~min}$ ). To assess serum calcium, phosphorus, alkaline phosphatase, plasma cortisol and lipid per-oxidation, blood samples were collected from animals on the day of surgery (day $0)$ and at $7^{\text {th }}, 15^{\text {th }}, 30^{\text {th }}$ and $60^{\text {th }}$ day time points.

Statistical analysis: Data were subjected to statistical analysis by using one way analysis of variance (ANOVA), followed by Duncan test, using SPSS 17.0 version. The level of statistical significance for all compression was established at $\mathrm{P}<0.05$.

\section{Results and Discussion}

Serum calcium: In groups $\mathrm{A}$ and $\mathrm{C}$, a non-significant decrease $(\mathrm{P}>0.05)$ in serum calcium was recorded up to the $7^{\text {th }}$ day, and thereafter the values increased nonsignificantly till the end of the study period (Table-1), this was probably due to increased intestinal absorption [13]. Serum calcium levels have been shown to have a non-significant decrease up to 4 weeks followed by an elevation after ulnar segmental defect in canines [14].
In group $\mathrm{B}$, calcium levels decreased significantly $(\mathrm{P}<0.05)$ up to the $15^{\text {th }}$ day which was possibly due to increased rate of osteogenesis [15]. The level then increased significantly $(\mathrm{P}<0.05)$ till the $60^{\text {th }}$ day. This elevated serum calcium level might be due to high T3, T4 and TSH levels during $3^{\text {rd }}$ or $4^{\text {th }}$ week [16].

Serum phosphorus: In animals of groups A and B, phosphorus levels were significantly higher on the $30^{\text {th }}$ day and subsequently returned towards the baseline value. Animals in group $\mathrm{C}$ showed significant increase in phosphorus levels up to the $15^{\text {th }}$ day and later decreased up to $60^{\text {th }}$ day but remained significantly higher than the baseline value (Table-2). All the values were within the normal physiological limits. These results are in agreement with the findings of Paskalev [17].

Serum alkaline phosphatase: In group A, the mean value of ALP showed non-significant increasing trend $(\mathrm{P}>0.05)$ up to $30^{\text {th }}$ day and thereafter it decreased significantly $(\mathrm{P}<0.05)$ till the $60^{\text {th }}$ day. In the animals of group $\mathrm{B}$, alkaline phosphatase showed a significantly higher value on $15^{\text {th }}$ day and a decrease on $30^{\text {th }}$ day which was significantly $(\mathrm{P}<0.05)$ higher as compared to the baseline value (Table-3). These observations were in agreement with the earlier findings [18]. In group C, ALP levels showed a significantly $(\mathrm{P}<0.05)$ increasing trend up to the $15^{\text {th }}$ day and thereafter it showed a decreasing trend but remained significantly $(\mathrm{P}<0.05)$ higher than the baseline value. SMF stimulates bone formation by promoting osteoblast differentiation and/or activation due to significant increase in the two bone markers alkaline phosphatase and osteocalcin [19].

Plasma cortisol: In the animals of groups A, cortisol value increased significantly $(\mathrm{P}<0.05)$ up to the $15^{\text {th }}$ 
Table-4. Mean \pm SE values of cortisol $(\mu \mathrm{g} / \mathrm{dl})$ in different groups at different intervals.

\begin{tabular}{llllll}
\hline Group & $\mathbf{0}$ day & $\mathbf{7}$ day & $\mathbf{1 5}$ day & $\mathbf{3 0}$ day & $\mathbf{6 0}$ day \\
\hline $\mathrm{A}$ & $1.18^{\mathrm{a}} \pm 0.08$ & $1.65^{\mathrm{bCB}} \pm 0.07$ & $1.99^{\mathrm{CB}} \pm 0.10$ & $1.56^{\mathrm{ab}} \pm 0.22$ & $1.38^{\mathrm{ab}} \pm 0.09$ \\
$\mathrm{~B}$ & $1.28 \pm 0.10$ & $1.48^{\mathrm{AB}} \pm 0.07$ & $1.43^{\mathrm{A}} \pm 0.08$ & $1.30 \pm 0.11$ & $1.35 \pm 0.19$ \\
$\mathrm{C}$ & $1.26 \pm 0.06$ & $1.27^{\mathrm{A}} \pm 0.22$ & $1.42^{\mathrm{A}} \pm 0.08$ & $1.68 \pm 0.24$ & $1.47 \pm 0.14$ \\
\hline
\end{tabular}

Values in the same row without a common superscript letter a- e are significantly different $(P<0.05)$ Values in the same column without a common superscript letter $A$ - $E$ are significantly different $(P<0.05)$.

Table-5. Mean \pm SE values of lipid peroxidation $(\mathrm{nmol} \mathrm{MDA} / \mathrm{g} \mathrm{Hb}$ ) in different groups at different intervals.

\begin{tabular}{llllll}
\hline Group & $\mathbf{0}$ day & $\mathbf{7}$ day & $\mathbf{1 5}$ day & $\mathbf{3 0}$ day & $\mathbf{6 0}$ day \\
\hline $\mathrm{A}$ & $1.65^{\mathrm{a}} \pm 0.08$ & $3.27^{\mathrm{b}} \pm 0.54$ & $3.05^{\mathrm{b}} \pm 0.25$ & $2.45^{\mathrm{ab}} \pm 0.57$ & $2.11^{\mathrm{ab}} \pm 0.16$ \\
$\mathrm{~B}$ & $1.79^{\mathrm{a}} \pm 0.17$ & $2.83^{\mathrm{b}} \pm 0.33$ & $2.51^{\mathrm{ab}} \pm 0.30$ & $2.02^{\mathrm{a}} \pm 0.13$ & $2.00^{\mathrm{a}} \pm 0.14$ \\
$\mathrm{C}$ & $1.89^{\mathrm{a}} \pm 0.17$ & $2.91^{\mathrm{b}} \pm 0.25$ & $2.46^{\mathrm{a}} \pm 0.19$ & $2.27^{\mathrm{a}^{\mathrm{a}} \pm 0.17}$ & $2.21^{\mathrm{a}} \pm 0.29$ \\
\hline
\end{tabular}

Values in the same row without a common superscript letter a- e are significantly different $(P<0.05)$ Values in the same column without a common superscript letter A- E are significantly different $(P<0.05)$.

day, then decreased non-significantly $(\mathrm{P}>0.05)$ up to the $60^{\text {th }}$ day. Cortisol level did not vary considerably at different intervals in the groups $\mathrm{B}$ and $\mathrm{C}$. The values at different time intervals in these groups did not differ significantly $(\mathrm{P}>0.05)$ from the respective base values (Table-4). The findings for group B animals were in agreement with those in horses, where a sharp increase in blood cortisol level was recorded after $30 \mathrm{~min}$ of EA treatment [20]. In group $\mathrm{C}$, non-significant $(\mathrm{P}>0.05)$ high cortisol levels were observed, that might be due to stimulation of ACTH, which was also reported after 50 $\mathrm{Hz}$ magnetic field application in guinea pigs [21].

Lipid peroxidation: In animals of group A, LPO levels increased significantly $(\mathrm{P}<0.01)$ on $7^{\text {th }}$ day. Thereafter, the values decreased toward the baseline value and remained significantly $(\mathrm{P}<0.05)$ higher up to $15^{\text {th }}$ day. In groups $B$ and $C$, the mean value of LPO was significantly $(\mathrm{P}<0.05)$ higher on $7^{\text {th }}$ day, then began to decline throughout the observation period. However, the baseline value did not differ significantly on successive intervals (Table-5). In earlier studies, oxidant level rose by the $2^{\text {nd }}$ and $3^{\text {rd }}$ weeks, perhaps due to callus formation and angiogenesis and also indicated that oxidative stress is proportional to the level of bone fracture trauma [22]. EA treatment displayed antioxidative and/or neuroprotective properties in rats having lesions induced with 6-hydroxy dopamine and these protective properties might be mediated, at least in part, by involving regulation of the antioxidant defense system [23].

\section{Conclusion}

In conclusion, animals which were subjected to the SMF as compared to the EA therapy showed better bone defect healing. Furthermore, physiological stress induced due to creation of bone defect, was also effectively ameliorated by SMF and electro acupuncture therapy. However, signs of healing were observed earlier in animals subjected to SMF therapy.

\section{Authors' contributions}

GS and MMSZ designed the study. GS conducted the study. HPA, RJ and MB contributed in conducting and analyzing the data. All authors read and approved the final manuscript.

\section{Acknowledgements}

The financial support provided by the Director of Indian Veterinary Research Institute (IVRI), Izatnagar for this study is duly acknowledged. The authors are thankful to Dr Amit Kumar Dohare, PhD student in Biostastics, IVRI, India for assisting in statistical analysis of data.

\section{Competing interests}

The authors declare that they have no competing interests.

\section{References}

1. Steyn, P. E., Ramey, D. W., Kirschvink, J., and Uhrig, J. (2000) Effect of SMF on blood flow to the metacarpus in horses. J. Am. Vet. Assoc., 217: 874-877.

2. Jansen, J. H.,, Van der Jagt, O. P., Punt, B. J., Verhaar, J. A., van Leeuwen, J. P., Weinans, H., and Jahr, H. (2010) Stimulation of osteogenic differentiation in human osteoprogenitor cells by pulsed electromagnetic fields: an in vitro study. BMC Musculoskelet Disord. 23(11):188.

3. Bruce, G. K., Howlett, C. R. and Huckstep R. L. (1987) Effect of a static magnetic field on fracture healing in rabbit radius: preliminary results. Clin Orthop Relat Res 222: 300-306.

4. Saifzadeh, S., Rezazadeh, G., Naghadeh, B. D. and Ajodani, M. (2006) Enhancement of bone healing by static magnetic field in the dog: biomechanical study. Iranian Journal of Veterinary Surgery, 1:58-64.

5. Huang, H. M., Lee, S. Y., Yao, W. C., Lin, C. T. and Yeh, C. Y. (2006) Static magnetic fields up-regulate osteoblast maturity by affecting local differentiation factors. Clin Orthop Relat Res 447:201-208.

6. Morris, C. E. and Skalak T. C. (2008) Acute exposure to a moderate strength static magnetic field reduces edema formation in rats. Am. J. Physiol. Heart Circ. Physiol., 294(1): 50-57.

7. Null, G. (1998) Healing with magnets. 1st Edn., New York, carroll and Graf publishers Inc., PP: 120-135.

8. $\mathrm{Fu}, \mathrm{H}$. (2000) What is material base of acupuncture ? The nerves. Medical Hypothesis., 54(3): 358-359.

9. Bakhtiari, J. and Zama, M. M. S. (1998) Annual International Congress on Veterinary Acupuncture, pp: 186194.

10. Zama, M. M. S., Gupta, O. P., Singh, G. R. and Swarup, D. (1999) Post operative acupuncture therapy in fracture of femur: clinical, haematological and biochemical studies in goats. Indian J Vet Surg, 20: 86-87.

11. Nakajima, M., Inoue, M., Hojo, T., Inoue, N., Tanaka, K., 
Takatori, R. and Itoi, M. (2010) Effect of EA on the healing process of tibia fracture in a rat model: a randomised controlled trial. Acupunct Med.28: 140-143.

12. Amarpal., Kinjavdekar, P., Aithal, H. P., Pawde, A. M. and Pratap, K. (2010) A comparision of xylazine-ketamine, acepromazine-ketamine, and medetomidine-ketamine combination for general anaesthesia in rabbits. Scand. J. Lab. Anim. Sci., 37: 223-229.

13. Asghari, A., Haghdost, I. S. and Gharachorlou, A. (2011) Evaluation of the effect of different amounts of vitamin D3 in bone healing and maintenance of serum vitamin $\mathrm{D}$ and $\mathrm{Ca}$ concentration in the rabbit. Advances in Environmental Biology, 5(7): 1548-1553.

14. Rao, T. M., Lakshmipathi, G. V., Sastry, T. P. and Ramakrishna, O. (2001) Biochemical changes following ulnar segmental defect repair with fibrillar collagen hydroxyl-apetite and porous hydroxy-apetite implant in canines. Indian J. Anim. Res., 35(2): 112 - 115.

15. Darendililer, M., Darendililer, A. and Sinclair, P. (1997) Effect of static magnetic and pulsed electromagnetic fields on bone healing. Int. J. Adult Orth. Orthog. Surg. 12: 45-53.

16. Shen, M., Qi, X., Huang, Y., Lü, Y. and Cai, W. (1999) Effects of acupuncture on the pituitary-thyroid axis in rabbits with fracture. J. Tradit. Chin. Med., 19: 300-3.

17. Paskalev, M., Krastev, S. and Filipov, J. (2005) Changes in some serum bone markers after experimental fracture and intramedullary osteosynthesis in dogs. Trakia Journal of Sciences, 3(5): 46-50.

18. Tembhurne, R.D., Gahlod, B.M., Dhakate, M.S., Akhare S.B., Upadhye S. V., and Bawaskar S. S. (2010) Management of femoral fracture with the use of horn peg in canine. Vet. World., 3(1): 37-41.

19. Yamamoto, Y., Ohsaki, Y., Goto, T., Nakasima, A. and Iijima, T. (2003) Effects of SMFs on bone formation in rat osteoblast cultures. J. Dent. Res., 82:962-66.

20. Cheng, R., McKibbin, L., Roy, B. and Pomeranz, B. (1980) EA elevates blood cortisol levels in naive horses; sham treatment has no effect. Int. J. Neurosci., 10: 95-97.

21. Zare, S., Hayatgeibi, H., Alivandi, S. and Ebadi, A. G. (2006). Effects of 50hz magnetic field on some factors of the immune system in male guinea pigs. Internet $J$ Med Tech, 3(1): 1-6.

22. Prasad, G., Dhillon, M. S., Khullar, M. and Nagi, O. N. (2003). Evaluation of oxidative stress after fractures: A preliminary study. Acta Orthopadica Belgica, 69(6): 546551.

23. Yu, Y. P., Ju, W. P., Li, Z. G., Wang, D. Z., Wang, Y. C. and Xie, A. M. (2010). Acupuncture inhibits oxidative stress and rotational behavior in 6- hydroxydopamine lesioned rat. Brain Res., 1336: 58-65. 